ISSN: 2162-3104 Print/ ISSN: 2166-3750 Online

Volume 10, Issue S3 (2020), pp. 108-125

(C) Journal of International Students

https://ojed.org/jis

\title{
The Emotional Experiences of Indonesian PhD Students Studying in Australia during the COVID-19 Pandemic
}

\section{Pengalaman Emosional Mahasiswa Program Doktor Asal Indonesia Belajar di Australia selama Pandemi COVID-19}

\author{
Supiani \\ Universitas Islam Kalimantan MAB Banjarmasin, Indonesia \\ Dina Rafidiyah \\ Universitas Muhammadiyah Banjarmasin, Indonesia \\ Yansyah \\ Universitas Muhammadiyah Banjarmasin, Indonesia \\ Hafizhatu Nadia \\ Universitas Muhammadiyah Banjarmasin, Indonesia
}

\begin{abstract}
This narrative study aims to explore the emotional experiences of two Indonesian students pursuing a doctorate $(P h D)$ degree in Australia during the COVID19 pandemic. Drawing on semi-structured interview data, we found that the prevalence of COVID-19 affected the participants' emotions and behaviors. Both participants experienced different emotions and behaviors in facing various challenges during the pandemic. The study stresses the importance of independence, family support, social support, and university support that the participants needed to reduce their anxiety and stress due to some social restrictions during the outbreak of COVID-19, especially for those who are extrovert.
\end{abstract}




\begin{abstract}
ABSTRAK: Penelitian naratif ini bertujuan untuk mengeksplorasi pengalaman emosional dua orang mahasiswa program doktor asal Indonesia yang sedang belajar di Australia selama pandemi COVID-19. Berdasarkan data wawancara semi-terstruktur, kami menemukan bahwa dampak COVID-19 memengaruhi emosi dan perilaku partisipan. Kedua partisipan mengalami emosi dan perilaku yang berbeda satu sama lain dalam menghadapi berbagai tantangan selama pandemi. Penelitian ini menekankan pentingnya kemandirian, dukungan keluarga, dukungan sosial dan dukungan universitas yang diperlukan oleh partisipan untuk mengurangi perasaan cemas dan stres yang diakibatkan oleh berbagai pembatasan sosial di masa COVID-19, terutama bagi partisipan yang berkepribadian ekstrover.
\end{abstract}

Keywords: COVID-19, emotional experience, Indonesia, students' emotions, PhD students [COVID-19, pengalaman emosi, Indonesia, emosi mahasiswa, mahasiswa doktor]

\title{
PENDAHULUAN
}

Penyebaran wabah COVID-19 mengubah wajah pendidikan dunia. COVID-19 membawa dampak disrupsi pendidikan dalam skala yang begitu luas berupa penutupan sementara sekolah hingga universitas. Pembelajaran yang semula berbentuk tatap muka harus beralih menjadi pembelajaran daring. Misalnya, dalam konteks pendidikan tinggi, peralihan mendadak ini menimbulkan beragam tantangan, seperti ketidaksiapan institusi dan mahasiswa untuk melakukan pembelajaran daring secara penuh. Telah banyak penelitian yang membahas tentang dampak COVID-19 terhadap pendidikan (Baloran, 2020; Bao, 2020; Demuyakor, 2020; Quattrone, Borghini, Emdin \& Nuti, 2020; Xue, $\mathrm{Li}$, Li \& Shang, 2020), namun pembahasan yang menekankan pengalaman emosional mahasiswa internasional masih terbatas. Berdasarkan penelitian oleh Nguyen dan Balakrishnan (2020), pandemi COVID-19 memiliki dampak signifikan terhadap kesehatan mental mahasiswa internasional. Oleh karena itu, penelitian yang membahas perspektif sisi psikologis diperlukan agar bisa memahami permasalahan mahasiswa internasional secara komprehensif.

Mahasiswa internasional terutama yang berasal dari Asia menjadi sorotan selama krisis kesehatan yang disebabkan oleh COVID-19. Di Australia, misalnya, rasisme terjadi dengan menganggap bahwa orang berwajah Asia adalah penyebar virus. Tanggapan pemerintah pun menjadi tolok ukur penting bagi keberlangsungan dan reputasi Australia dalam penyelenggaraan pendidikan internasional (Soong, Kerkham, Reid-Nguyen, Lucas, Geer \& Mills-Bayne, 2020). Penelitian yang dilakukan oleh Ma dan Miller (2020) juga menunjukkan bahwa mahasiswa Cina memiliki tingkat stres yang tinggi diakibatkan oleh diskriminasi pemberitaan media. Berdasarkan pemaparan ini, menarik untuk membahas tentang bagaimana pengalaman emosional, tantangan yang dirasakan dan strategi mahasiswa asal Indonesia yang sedang menempuh pendidikan doktor di luar negeri, khususnya di Australia dalam menghadapi berbagai masalah tersebut. 


\section{LANDASAN KONSEPTUAL}

\section{Mahasiswa Internasional dan COVID-19}

COVID-19 telah memberikan dampak yang besar terhadap penyelenggaraan pendidikan internasional (Fischer, 2020). Sebelumnya, mahasiswa internasional telah memiliki tantangan berupa stereotip, perbedaan budaya dan isu terkait bahasa (Maddamsetti, Flennaugh \& Rosaen, 2018). Ketika COVID-19 mewabah, tantangan seperti peralihan pembelajaran dari tatap muka ke daring (Demuyakor, 2020) dan permasalahan terkait rasisme menjadi tambahan kompleksitas yang harus dihadapi oleh mahasiswa internasional, khususnya yang berasal dari negara-negara Asia. Pembelajaran daring menjadi solusi yang bisa ditawarkan untuk keberlangsungan pendidikan selama krisis COVID-19 (Bilecen, 2020). Meskipun pembelajaran daring telah lama diperkenalkan, tidak semua mahasiswa merasa nyaman atau siap dengan metode ini seperti keluhan mereka terhadap akses internet yang lambat (Demuyakor, 2020).

Tran (2020) menjelaskan tujuh faktor penting yang berpengaruh terhadap kehidupan akademik, sosial dan psikologis mahasiswa internasional, seperti (1) keterkaitan dengan isi dan proses pembelajaran, (2) ikatan emosi dengan pengajar dan mahasiswa internasional lainnya, (3) keterlibatan dengan komunitas kampus, (4) interaksi sosial, (5) hubungan dengan jaringan profesi dan sosial, (6) akses komunikasi dengan keluarga dan (7) koneksi digital. Akses mahasiswa internasional dengan ketujuh faktor ini berubah karena terjadi pembatasan berskala besar selama pandemi, terutama terkait isu interaksi sosial. Adaptasi dengan kebiasaan baru berpengaruh terhadap berbagai aktivitas, termasuk strategi belajar yang digunakan oleh mahasiswa.

\section{Pengalaman Emosional}

Pendidikan tinggi bertujuan untuk mendidik para mahasiswa mampu berpikir secara mandiri, sehingga kajian tentang pengalaman yang mereka alami merupakan hal yang sangat penting (Radley, 1979). Pengalaman sosial dan emosional merupakan aspek yang berkaitan dengan performa akademik seseorang (Glass \& Westmont, 2014). Mengkaji pengalaman sosial dan emosional mahasiswa internasional dapat membuka perspektif yang lebih luas tentang bagaimana lingkungan dan keadaan sosial budaya berpengaruh terhadap proses belajar. COVID-19 telah membatasi ruang dan gerak masing-masing individu. Hal ini bisa menyebabkan kesepian (loneliness), terutama bagi mahasiswa internasional yang jauh dari keluarga atau tanah airnya. Selanjutnya, Hawkley dan Cacioppo (2010) mendefinisikan kesepian sebagai perasaan subjektif yang mengakibatkan seseorang merasa terasing.

Pengalaman emosional juga erat hubungannya dengan kesejahteraan psikologis (psychological well-being) seseorang terhadap keadaan yang sedang terjadi. Sebagaimana disebutkan sebelumnya, COVID-19 memberikan tekanan psikologis terhadap mahasiswa terkait perubahan pembelajaran dan pembatasan 
kehidupan sosial mereka. Ryff (1989) menawarkan enam faktor utama yang memengaruhi keadaan psikologis seseorang. Keenam faktor tersebut meliputi (1) otonomi, (2) keakraban dengan lingkungan sekitar, (3) hubungan positif dengan orang lain, (4) tujuan hidup, (5) penerimaan terhadap diri sendiri dan (6) pengembangan diri. Keenam faktor ini juga memengaruhi persepsi emosional seseorang tentang kepuasan dan kebahagian dalam hidupnya. Kesejahteraan psikologis ini memiliki hubungan erat dengan kesuksesan akademik (Brunsting, Zachry, Liu, Bryan, Fang, Wu \& Luo, 2019). Kesejahteraan psikologis setiap orang bisa berbeda bergantung pada tipe kepribadian tiap individu (Crea \& Francis, 2020) dan dukungan sosial. Brunsting, Zachry, Liu, Bryan, Fang, Wu, dan Luo (2019) juga menegaskan dukungan sosial yang berasal dari fakultas, mahasiswa domestik dan mahasiswa internasional lain menjadi faktor yang harus diperhatikan agar mahasiswa internasional merasa diterima dan dihargai di lingkungan baru mereka.

\section{METODOLOGI}

Penelitian ini menggunakan desain naratif (Clandinin \& Connelly, 2000) dengan mengeksplorasi cerita pengalaman emosional mahasiswa program doktor asal Indonesia di Australia dalam belajar dan berinteraksi dengan dosen pembimbing serta rekan sesama mahasiswa di masa pandemi COVID-19. Cerita pengalaman emosional partisipan bersifat personal dengan mengungkapkan perasaan, tantangan yang dialami mereka dan strategi yang dilakukan selama pandemi COVID-19 di Australia.

\section{Partisipan}

Dua orang perempuan dengan nama samaran Weni (43 tahun) dan Santi (42 tahun) bersedia secara sukarela menjadi partisipan dalam penelitian ini. Mereka adalah mahasiswa program doktor berasal dari Indonesia yang sedang menempuh pendidikan di perguruan tinggi yang berbeda di Australia. Weni belajar di sebuah universitas negeri di Melbourne dan sudah berada di Australia sejak Desember 2019. Sedangkan, Santi menempuh studi di salah satu universitas negeri di New South Wales sejak Desember 2018. Mereka samasama berasal dari perguruan tinggi Islam, mendapatkan beasiswa MORA yang dikelola oleh Kementerian Agama Republik Indonesia, dan mengambil jurusan Pendidikan Bahasa Inggris (Teaching English to Speakers of Other Languages).

Perekrutan partisipan penelitian ini dilakukan dengan tiga alasan utama: (1) kesediaan mereka untuk memberikan informasi yang berkaitan dengan pengalaman emosi mereka selama pandemi COVID-19 di Australia; (2) adanya kedekatan emosional, pertemanan yang akrab sebagai dosen di Program Studi S1 Pendidikan Bahasa Inggris dan (3) partisipan dan kami sebagai peneliti berasal dari kota yang sama di Provinsi Kalimantan Selatan, Indonesia. Ketiga alasan tersebut memudahkan kami untuk mengeksplorasi pengalaman emosional mereka selama COVID-19 di Australia secara mendalam. 


\section{Pengumpulan dan Analisis Data}

Dalam menggali data naratif, kami menggunakan wawancara semi-terstruktur untuk mendapatkan pengalaman emosional mereka pada saat belajar di program doktor selama COVID-19. Sebelum mewawancarai kedua partisipan, kami terlebih dahulu menghubungi mereka melalui obrolan dan telepon WhatsApp untuk meminta kesediaan partisipasi mereka dalam penelitian ini. Setelah mereka bersedia, kemudian kami menegosiasikan dan membicarakan waktu wawancara yang sesuai dengan waktu luang kedua partisipan. Kegiatan wawancara dilakukan dengan menggunakan aplikasi Zoom agar kami dapat bertatap muka langsung dengan partisipan dan melihat ekspresi emosi mereka dengan baik. Harrell dan Bradley (2009) menegaskan bahwa wawancara dapat dilakukan melalui tatap muka atau melalui telepon, tergantung pada jenis riset dan tingkat akses terhadap partisipan. Kami menggunakan bahasa Indonesia selama wawancara untuk memudahkan komunikasi, tetapi kami memberikan kebebasan partisipan untuk menjawab wawancara menggunakan bahasa Indonesia atau kombinasi bahasa Indonesia dan bahasa Inggris. Setiap wawancara berlangsung sekitar 30-60 menit.

Dua partisipan diwawancarai secara terpisah dengan waktu yang berbeda, menyesuaikan dengan waktu luang mereka. Pada umumnya, wawancara dilaksanakan pada siang dan sore hari. Wawancara dilakukan dalam suasana santai agar partisipan merasa nyaman dan terbuka untuk mengungkapkan pengalaman emosi yang mereka alami. Ketika wawancara berlangsung, kami meminta izin untuk merekam percakapan atau jawaban mereka melalui fitur di Zoom. Transkrip wawancara yang telah dibuat dan kemudian dianalisis berdasarkan tema yang sering muncul. Dalam menganalisis data, tema yang muncul diidentifikasi melalui pendekatan induktif (Braun \& Clarke, 2006). Analisis dengan pendekatan induktif dapat dilakukan melalui identifikasi pola dan tema yang muncul dalam data wawancara (Harrell \& Bradley, 2009). Kami membagi cerita dan pengalaman emosional kedua partisipan pada beberapa tema dengan mengidentifikasi data wawancara. Tiga hal yang menjadi tema utama pada penelitian naratif ini, yaitu perasaan emosional mereka, tantangan yang mereka alami dan cara atau strategi untuk mengatasi tantangan tersebut. Ketiga hal tersebut diambil berdasarkan tema yang jelas tergambar secara induktif dalam cerita atau pengalaman mereka selama studi program doktor di Australia.

Pendekatan holistik yang digunakan dalam menggarisbawahi pemilihan tema dan cerita merupakan suatu proses cara menemukan data dari makna dan pengalaman hidup para partisipan (Van Manen, 1990; 1997). Kemudian, kami mentranskrip data wawancara partisipan secara lengkap sesuai dengan cerita mereka. Widodo (2014) menegaskan bahwa data wawancara yang ditranskrip adalah suatu cara untuk merepresentasikan, menganalisis dan menginterpretasikan data yang sudah disampaikan. Setelah itu, transkrip wawancara kami kirim kembali ke kedua partisipan melalui obrolan WhatsApp untuk dicek ulang. Jika mereka berkeinginan untuk melengkapi data yang 
dirasakan belum tepat atau menambahkan yang sudah ada agar lebih jelas dan akurat, kedua partisipan bisa mengembalikan transkripsi data wawancara dengan umpan balik kepada kami. Pada tahap akhir, kami mengirimkan transkrip data ke partisipan untuk mengecek ulang (member checking) apakah data yang ditranskripsi sesuai dengan data naratif yang disampaikan oleh kedua partisipan (Fishman, 2001).

\section{TEMUAN PENELITIAN}

Berdasarkan hasil analisis tematik induktif ditemukan tiga tema hasil penelitian, yaitu pengalaman emosional partisipan selama COVID-19, tantangan emosional partisipan dan strategi mengatasi tantangan emosional tersebut.

\section{Pengalaman Emosional Partisipan selama COVID-19}

Penyebaran COVID-19 di Australia memunculkan cerita emosional dari kedua partisipan yang sedang menempuh studi doktor. Mereka merasakan suatu perubahan yang signifikan dalam belajar, bimbingan disertasi dengan dosen pembimbing dan berinteraksi sosial dengan teman-teman Indonesia dan mancanegara. Dengan situasi COVID-19 yang sangat mengkhawatirkan ini, Pemerintah Australia memberlakukan sistem karantina wilayah untuk warga negara asing yang akan masuk ke Australia dan menetapkan sistem pembelajaran daring, khususnya di perguruan tinggi. Hal ini membuat para mahasiswa internasional khususnya di Australia yang sedang menempuh pendidikan mengalami perasaan emosional yang beragam dalam menyikapi COVID-19. Mereka bisa beradaptasi terhadap perubahan yang terjadi. Weni dan Santi menyikapi keadaan ini dengan emosi, karakter dan cara pandang yang berbeda karena sebelum wabah ini muncul, mereka merasa nyaman untuk belajar, berinteraksi sosial dan bertemu secara tatap muka dengan dosen pembimbing mereka. Ketidakhadiran keluarga juga berdampak pada perasaan emosional yang membuatnya merasa sendiri di tengah situasi yang sulit. Kehadiran keluarga sangat berarti bagi Weni dalam hal memberi dukungan dan semangat untuk tetap kuat dan tegar menghadapi situasi sekarang. Seperti yang disampaikan oleh Weni pada saat wawancara, dia merasa cemas dan sedih karena suaminya tidak bisa berangkat ke Australia untuk menemani dia selama kuliah dikarenakan adanya COVID-19:

Saya merasa stres dan sedih masalahnya suami saya sudah beli tiket mau berangkat ke sini untuk menemani saya di sini. Padahal visa sudah granted bulan Februari dan rencananya berangkat bulan April, karena masih banyak pekerjaan. Seharusnya berangkat Maret, tetapi beliau harus menyelesaikan pekerjaan. Waduuh saya pusing ketika muncul COVID-19, akhirnya tidak bisa datang. Bagi saya kehadiran suami sangat penting untuk support studi saya di sini. Di sisi lain, saya sedih juga karena tidak bisa jalan-jalan ke cafe atau refreshing bersama teman-teman karena sekarang semua kegiatan 
Perasaan emosional Weni tersebut berbanding terbalik dengan yang dirasakan oleh Santi. Santi tidak merasa kesepian di masa sebelum dan selama COVID-19 karena dia ditemani oleh keluarga (suami dan anak) yang tinggal satu rumah bersama-sama di Australia. Oleh karena itu, dia merasa senang dan menganggap bahwa adanya wabah ini tidak memengaruhi emosinya walaupun ada aturan pembatasan aktivitas sosial secara kontak langsung atau fisik. Dia memahami karakternya yang cenderung introver sehingga dengan adanya COVID-19, dia mengatakan keadaan ini adalah suatu berkah (blessed) karena berkurangnya tuntutan untuk interaksi sosial di kampus dan masyarakat. Sebagaimana dia ceritakan dalam wawancara:

Saya senang dan enjoy karena ada suami dan anak menemani saya sebelum wabah ini dan sampai sekarang di sini. Well...I know that COVID-19 is a serious disease, but for me if you are asking for my opinion, it is blessing for me, I felt blessed. Saya tidak masalah, my character I don't like any social gatherings, jadi kan sebelum COVID-19 memang ada undangan dari temanteman, ayooo datang ke rumah, but sekarang kan tidak ada lagi undangan dari teman-teman atau kegiatan lainnya. So, it is okay. I like it. Mungkin juga sesuai dengan karakter saya, because my character is actually introvert, I like to do actvities alone actually. Heehehee (sambil tetawa kecil) (Santi, Wawancara Zoom, 9 Agustus 2020)

Perubahan moda komunikasi dalam belajar dan bimbingan riset dengan dosen pembimbing yang dilakukan secara daring dengan bantuan aplikasi Zoom juga memberikan dampak psikologis terhadap tiap individu. Weni dan Santi sama-sama belum terbiasa belajar dan bimbingan secara daring, sehingga hal ini memaksa mereka untuk belajar mandiri memahami penggunaan teknologi khususnya Zoom dan mencari sumber ilmu pengetahuan atau referensi jurnaljurnal terkait riset yang mereka kerjakan. Pemberlakuan situasi dari tatap muka langsung luring menjadi daring membuat mereka merasa kurang nyaman dan agak sulit untuk memunculkan gairah atau motivasi semangat belajar. Sebagaimana yang diceritakan oleh Weni bahwa:

Feelingnya sangat beda, terakhir saya bertemu langsung berhadapan dengan supervisor di bulan Maret. Saat itu saya merasa nyaman konsultasi dan lebih leluasa bertanya, tapi sekarang lewat Zoom sepertinya kurang nyaman, agak kaku bimbingan. Pada dasarnya pengaruh online itu perpindahan belajar dari kampus ke rumah, padahal di kampus itu ada macam-macam fasilitas seperti ada desk atau office, kita bisa seharian di situ belajar, bisa makan, kerja, ngeprint pokoknya full untuk diri sendiri dan ke perpustakaan cari referensi. Setelah pindah ke rumah suasananya jadi berbeda. Kalau di kampus saya lebih semangat belajar, tapi kalau sudah di rumah jadi berkurang motivasinya, agak malasan. Suasana di rumah memang berbeda dengan suasana di kampus. Kalau saya ke perpustakaan 
lihat orang belajar, pasti saya semangat untuk belajar. Tapi kalau di rumah ini kayanya saya kurang semangat jadinya. Kalau di rumah untuk lebih semangat belajar memerlukan waktu lama, apalagi di rumah saya sendirian. Jadi situasi ini penuh perjuangan dari bulan Maret, April sampai sekarang. (Weni, Wawancara Zoom, 18 Juli 2020)

Sama halnya dengan Weni, Santi juga merasakan ketidaknyamanan dan ketidakleluasaan dalam belajar dan bimbingan disertasi melalui daring. Dia merasa belum terbiasa dengan situasi lingkungan pembelajaran virtual, misalnya saat dia harus melakukan aktivitasnya secara daring seperti mencari referensi, meminjam buku-buku di perpustakaan dan merekam pesan atau ucapan dosen pembimbing ketika bimbingan disertasi. Hal-hal demikian dijalani secara mandiri oleh Santi tanpa melakukan kontak fisik sosial. Dia menceritakan perasaan yang dialaminya ketika belajar dan bimbingan disertasi secara daring:

Dulu sangat mudah sebelum COVID-19, saya ke perpustakaan meminjam buku, cari referensi dan ada fasilitas ruang kerja di mana saya baca dan belajar sendiri. Tetapi dengan kejadian sekarang, saya belum bisa pergi lagi ke kampus. Kegiatan belajar di rumah saja dan meminjam buku dengan online misalnya cari-cari jurnal, buku-buku di website perpustakaan. Jadi saya hanya request online, mengirim email, terus dibalas untuk bisa diambil bukunya di perpustakaan. Begitu juga bimbingan disertasi dengan supervisor secara online dengan jadwal dua kali sebulan, tetapi sebenarnya saya merasa tidak begitu suka seperti ini karena saya sudah terbiasa offline. Dulu waktu offline saya biasa mencatat apa yang disampaikan oleh supervisor. Kalau pakai Zoom saya tidak perlu lagi mencatat tapi terkadang saya bisa lupa dan tidak sadar apa sudah merecord, apa pertemuan Zoom ini, terkadang bingung sendiri. Kemudian, saya diingatkan oleh supervisor untuk merecord ucapan beliau saat online. (Santi, Wawancara Zoom, 9 Agustus 2020)

\section{Tantangan Emosional Partisipan selama COVID-19}

Tantangan menjadi mahasiswa program doktor sangat berbeda dengan masa studi S1 (sarjana) dan S2 (magister). Tantangannya terasa lebih berat dengan munculnya wabah COVID-19 di Australia. Selama COVID-19 terjadi, Weni dan Santi tidak menghadiri kelas lagi dan tidak harus bersosialisasi di kampus serta berinteraksi langsung dengan orang lain. Secara umum, mereka dituntut untuk mengerjakan segala kegiatan akademik atau aktivitas lain secara mandiri seperti belajar dan konsultasi riset disertasi dengan dosen pembimbing melalui Zoom. Weni menceritakan dalam wawancaranya:

Pada umumnya kami di sini membiasakan play solo atau mandiri begitu, karena topik penelitian kami juga beda satu sama lain, jadi lebih banyak konsultasi ke supervisor masing-masing. Ini merupakan suatu tantangan bagi saya yang dituntut harus terbiasa belajar dan riset serta dikerjakan sendiri. Dulu waktu kuliah S2 banyak diskusi dengan teman-teman, ada kelas, dan 
mengerjakan tugas selalu bersama-sama. Jadi ini sangat berbeda, dipaksa harus siap secara mandiri, istilahnya "you have to be in your own". Dengan kesendirian ini, saya harus bisa menghandel jadwal bimbingan riset, mengatur diri dan waktu supaya disiplin. Kemudian supervisor memberikan tugas ke saya untuk baca-baca artikel di jurnal terkait riset dan malah bingungnya tidak ada penjelasan secara detail dari supervisor bagaimana bernavigasi dan memahami referensi jurnal. Bahkan, supervisor berkata dalam bahasa Inggris "what do you like? what are your interests?". Jadi, ini harus benar-benar mandiri untuk memahaminya. Memang saya agak shock dan bingung perasaannya saat itu, apalagi di masa COVID-19 ini. (Weni, Wawancara Zoom, 18 Juli 2020)

Weni juga menambahkan ceritanya terhadap tantangan lain yang dia hadapi selama wabah berlangsung dikarenakan susahnya bersosialisasi dengan teman-teman. Selain itu, keadaan kesendirian di negara orang membuat dia harus bisa bertahan hidup tinggal di rumah dengan tujuan agar terhindar dari wabah penyakit saat ini. Dia menyampaikan pada saat wawancara bahwa:

\begin{abstract}
Selain kesendirian belajar dan kesusahan bimbingan disertasi via online, secara sosial saya juga harus stay at home dan tidak boleh ke mana-mana paling cuma beli makanan, olah raga, jalan-jalan. Tapi semuanya itu dilakukan dengan kesendirian. Dengan kondisi ini, saya akhirnya tidak bisa kumpul-kumpul dan refreshing lagi bersama teman-teman karena aturannya harus menjaga jarak diri masing-masing. Intinya harus selamat dan sehat di negara orang. Itulah yang paling berat. Padahal saya sukanya kumpul sama teman-teman untuk menghilangkan rasa kesepian dan kejenuhan. (Weni, Wawancara Zoom, 18 Juli 2020)
\end{abstract}

Santi juga merasakan tantangan serupa yang dia alami, khususnya terkait dengan kelas dan bimbingan disertasi. Dibandingkan dengan Weni, Santi merespons lebih bijak dan santai terhadap pandemi COVID-19 dan pembatasan sosial berskala besar di Australia. Ketika diwawancarai, dia menyampaikan ceritanya dengan menggunakan bahasa Inggris dan bahasa Indonesia secara bergantian:

I don't have classes this year. I haven't met my supervisors and friends. So, it is difficult for me not to meet my supervisors especially. Sebelum COVID-19 saya bisa janjian untuk ketemuan tapi saat ini susah untuk mengatur waktu yang tepat. Mungkin supervisor sibuk juga...I don't know, but I enjoyed learning independently. Tapi yang jelas semua cukup dengan online saja kalau mau konsultasi atau bimbingan dengan supervisor, tapi saya merasa tidak puas, ketimbang dengan tatap muka karena ada yang kurang jelas untuk mendapatkan poin penjelasan supervisor. Di sisi lain, saya tertantang harus banyak baca jurnal dan kemudian diringkas bacaannya sesuai anjuran supervisor karena saya belum terbiasa hal demikian agak berat menjalaninya tapi saya ambil hikmah dan positifnya saja. Take it easy and relax. (Santi, Wawancara Zoom, 21 Juli 2020) 
Cerita kedua partisipan tersebut menggambarkan bahwa tantangan yang dialami mereka tidak jauh berbeda, terutama dalam hal belajar dan bimbingan disertasi. Akan tetapi, beban emosional yang dialami oleh Weni lebih berat dibandingkan Santi. Weni merasakan tekanan psikologis di masa-masa sulit ketika berkuliah di Australia dikarenakan jauh dari keluarga. Selanjutnya, keharusan untuk belajar mandiri dan adanya pembatasan fisik dan sosial yang diatur oleh pemerintah Australia tidak memungkinkan bagi dia untuk bisa berkumpul bersama teman-teman atau pergi ke suatu tempat untuk penyegaran. Sementara itu, Santi menyikapinya dengan berpikir positif terhadap penyesuaian lingkungan pembelajaran dan bimbingan riset secara daring. Kehadiran keluarga Santi (suami dan anaknya) di Australia dan karakter diri Santi yang introver berpengaruh pada emosi dan sikap positif yang diambilnya dari penyebaran COVID-19 di Australia.

\title{
Strategi Mengatasi Tantangan Emosional selama COVID-19
}

Strategi kedua partisipan berbeda satu sama lain tergantung cara pandang dan karakter mereka menyelesaikan tantangan di masa COVID-19. Walaupun dalam kesendirian dan kejenuhan, seperti yang dialami Weni, dia berupaya untuk membiasakan diri disiplin dengan membuat jadwal bimbingan disertasi regular dengan dosen pembimbing dan berkomitmen untuk belajar mandiri. Dia juga selalu berkomunikasi dengan keluarga dan teman-teman asal Indonesia atau negara lain di kampus maupun luar kampus melalui aplikasi WhatsApp. Weni menceritakan hal ini saat wawancara bahwa:

\begin{abstract}
Saya harus disiplin dan mandiri dalam melakukan kegiatan akademik khususnya bimbingan riset disertasi seperti membuat jadwal sendiri untuk belajar, membaca jurnal dan membuat ringkasannya, kemudian progresnya harus tetap dilaporkan atau dikomunikasikan ke supervisor sesuai jadwal yang sudah kami sepakati bersama. Kemudian, saya juga selalu telepon keluarga, suami dan anak di Indonesia via WhatsApp dan tentu komunikasi dengan teman-teman Indonesia atau negara lain di kampus Australia via Zoom juga saya lakukan supaya tetap semangat menjalani kuliah di sini. Sifat saya lebih suka berkawan atau bersosialisasi sama siapapun di sini. (Weni, Wawancara Zoom, 18 Juli 2020)
\end{abstract}

Selain itu, Weni pun mendapatkan dukungan dari pihak luar. Dia mendapatkan dukungan morel, materiel dan sosial dari dosen pembimbing dan pihak kampus untuk semua mahasiswa internasional yang sedang studi. Hal ini merupakan bentuk dukungan nyata dari kampus dan dosen pembimbing sehingga mereka merasakan kenyamanan selama studi di saat adanya wabah virus dan mengurangi beban finansial di situasi tersebut. Weni menyampaikan bahwa dia merasa senang dan nyaman karena adanya kepedulian dan dukungan kampus sehingga dia bisa tetap fokus untuk studi dan menyelesaikan risetnya tanpa halangan apapun. Pihak kampus dan asosiasi mahasiswa kampus di mana tempat Weni studi memberikan bantuan dalam bentuk dana, makanan, jaringan 
area lokal nirkabel gratis dan lain-lain untuk semua mahasiswa internasional yang terdampak oleh COVID-19:

Jadi kami bisa apply untuk dana bantuan itu, dan akhirnya kemarin dapat bantuan AU\$ 1,000 dari kampus istilahnya emergency fund. Karena kami dianggap pihak kampus yang kemungkinan mengalami kesulitan dalam belajar atau bimbingan online di rumah. Jadi dana tersebut bisa digunakan untuk beli data atau kuota internet, tapi kalau saya pergi ke kampus tidak masalah karena ada WIFI gratis untuk kami. Ada beberapa teman kami tidak bisa bekerja di cafe, misalnya, karena wabah ini cafenya ditutup akhirnya kehilangan pekerjaan, sehingga sangat memerlukan bantuan tersebut. (Weni, Wawancara Zoom, 18 Juli 2020)

Di kampus ini juga ada menyediakan makanan gratis dari asosiasi mahasiswa untuk mahasiswa dan bisa diambil di kampus. Biasanya ini ada jadwalnya untuk free lunch itu. Apalagi mahasiswa yang kehilangan pekerjaan karena tidak semua mahasiswa di sini beasiswa, ada yang biaya sendiri itu dapat makan cuma-cuma dari asosiasi mahasiswa di kampus. (Weni, Wawancara Zoom, 18 Juli 2020)

Kepedulian sosial dan saling membantu yang diberikan oleh kampus dan asosiasi mahasiswa merupakan wujud nyata untuk saling berbagi dan berempati terhadap mahasiswa domestik maupun internasional yang sedang menempuh pendidikan. Kampus dan asosiasi mahasiswa turut merasakan beban psikologis yang dialami oleh mahasiswa internasional, seperti rindu pada keluarga, kesepian, stres, bingung dalam studi, tidak ada pekerjaan dan masalah keuangan. Selain itu, mereka juga memberikan bantuan untuk meringankan permasalahan yang dialami para mahasiswa. Hal ini sangat membantu kebutuhan fisik dan mental Weni sebagai mahasiswa program doktor dari Indonesia untuk bisa bertahan hidup selama COVID-19 berlangsung. Dia juga bersyukur mendapatkan dukungan morel dan materiel serta empati dari dosen pembimbingnya yang sangat baik hati, suka membantu dan mengerti keadaan mahasiswa yang dibimbingnya:

Yang terpenting juga adalah support dari para supervisor yang selalu menghubungi mahasiswanya. Supervisor di sini sangat baik, malah waktu pertama kali mau bimbingan, supervisor menghubungi saya duluan. Kadang malu sendiri karena mereka yang menghubungi duluan. Mereka menghubungi saya bisa lewat email, lewat WhatsApp atau lewat Instagram. Sampai mereka tanya Weni, are you sure to have enough food, female stuff? Karena mau lockdown sekarang, if you have any difficulty, I can get you. Malah saya merasa tidak enak, saking baiknya mereka. Jadi mereka itu sangat care, bahkan terakhir itu If you don't have enough money, tell me. I can give you a loan. Padahal kan malu, iya kan? Pokoknya sangat care, sangat peduli, membantu. Pernah saya tidak ada kabar untuk beberapa hari, supervisor email saya, just check are you OK? Sampai dikirimi email seperti itu. (Weni, Wawancara Zoom, 18 Juli 2020) 
Sama seperti Weni, Santi juga melakukan hal serupa, yaitu belajar mandiri dan mendisiplinkan diri untuk tetap mengikuti jadwal dua kali bimbingan riset dalam sebulan yang sudah disepakatinya dengan dosen pembimbing melalui aplikasi Zoom. Dia berkomitmen untuk membaca artikel dari jurnal-jurnal internasional dan menuliskan serta melaporkan kemajuan belajarnya kepada dosen pembimbing tentang sejauh mana dia memahami konsep riset yang dia kerjakan. Selain kegiatan akademik yang dikerjakan, dia kadang-kadang pergi ke taman atau ke pantai di sekitar kampus baik sendirian atau bersama keluarga untuk menyegarkan pikiran dan menghibur diri di tengah kesibukan kegiatan belajar dan bimbingan disertasi selama COVID-19. Dia menceritakan strategi yang dilakukannya selama wabah terjadi:

Saya lebih banyak belajar mandiri dengan membaca, reading and after reading we write what we have read. Pertemuan dengan supervisor itu sudah dijadwal secara regular dan saya harus komitmen untuk patuh terhadap jadwal yang sudah ditetapkan dengan bimbingan daring. Artinya dalam satu bulan itu dua kali bimbingan. Jadi harus disiplin waktu agar bisa menyelesaikan studi. Kemudian, saya terkadang jalan-jalan sendiri ke kota dan ke pantai atau bisa juga bersama keluarga untuk refreshing dan santai-santai, tapi tetap mengikuti protokol kesehatan. (Santi, Wawancara Zoom, 9 Agustus 2020)

Selama masa pandemi COVID-19 ini, Santi pun bisa mengambil sisi positif. Dia mendapatkan banyak hikmah yang dirasakan saat wabah terjadi, diantaranya lebih mandiri, menerima keadaan, dan pasrah kepada Tuhan Yang Maha Esa. Selain itu, penerapan teknologi Zoom pun dirasakannya mendukung studinya selama di Australia, seperti untuk mengikuti kegiatan-kegiatan workshop dan seminar daring tentang topik riset yang dia kerjakan. Partisipasi di forum ilmiah tersebut sangat membantu dia dalam mengerjakan disertasi. Dia berharap bisa menyelesaikan program doktor tepat waktu, sebagaimana dinarasikan dalam data wawancara berikut:

Saya rasa saya bisa menggunakan Zoom akhirnya karena dulunya saya gagap teknologi tapi dipaksa harus bisa menyesuaikan diri di lingkungan daring. Jadi ini berarti saya tidak hanya bisa berkonsultasi dengan dosen pembimbing dengan daring, tetapi juga saya bisa ikut berpartisipasi di kegiatan workshop atau seminar daring terkait dengan riset saya. (Santi, Wawancara Zoom, 21 Juli 2020)

\section{PEMBAHASAN DAN KESIMPULAN}

Kedua partisipan sudah pernah menempuh pendidikan S-1 (sarjana) dan S-2 (magister) di Australia dan Malaysia. Dengan latar belakang pendidikan tersebut, kemahiran berbahasa Inggris, dukungan keluarga, kemampuan akademik dan adaptasi lintas budaya (tantangan sosial) bukan merupakan permasalahan yang berarti (Wolf \& Phung, 2019; Yu, Bodycott, \& Mak, 2019). Akan tetapi, pandemi COVID-19 memang berpengaruh sangat besar pada emosi 
yang dialami oleh mahasiswa internasional, khususnya Weni. Dia mengeluhkan kesepian atau kesendirian karena suaminya tertunda datang ke Australia disebabkan oleh COVID-19. Istilah kesepian tampaknya sangat sederhana, tetapi bila hal ini dipahami dari aspek psikologis, hal tersebut dapat memengaruhi fungsi fisiologis, mengurangi kualitas tidur, bahkan dapat meningkatkan morbiditas dan mortalitas. Sebagai makhluk sosial, tidak ada manusia yang bisa bertahan hidup tanpa adanya interaksi dengan lingkungan sosialnya (Hawkley \& Cacioppo, 2010). Keadaan ini memerlukan intervensi yang terus menerus baik dari diri sendiri maupun pihak lain seperti keluarga, teman, beserta pihak kampus agar dampak kesepian tersebut tidak makin memburuk. Pada kasus Weni, komunikasi dengan keluarganya melalui WhatsApp dan keaktifan serta kepedulian dosen pembimbing menghubungi dan mengecek kondisinya dirasa dapat meringankan beban psikologisnya. Hal ini juga sejalan dengan yang disampaikan oleh Radley (2006), bahwa kedekatan antara dosen pembimbing dan mahasiswa secara personal dapat membantu mengatasi situasi dan keadaan yang sulit.

Dukungan institusi pendidikan memiliki dampak tidak langsung pada penanganan kesepian yang dialami oleh mahasiswa (Brunsting, Zachry, Liu, Bryan, Fang, Wu, \& Luo, 2019). Selain itu, kesepian mereka juga dapat dikurangi dengan cara berkomunikasi dan berteman baik dengan mahasiswa lain atau komunitas senegara atau mancanegara. Interaksi sosial dapat mengurangi kesepian seseorang sehingga ini dapat memacu semangat untuk belajar. Sebagaimana disampaikan oleh Glass dan Westmont (2014), berempati dan berinteraksi dengan orang lain dapat berpengaruh pada keberhasilan akademik. Selanjutnya, hubungan lintas budaya mahasiswa domestik dan internasional juga dapat menumbuhkan rasa saling memiliki. Hubungan positif dengan orang lain, kemandirian dan kemampuan beradaptasi membuat mahasiswa internasional bisa bertahan untuk menyelesaikan pendidikannya. Partisipan dengan rentang usia 42-45 tahun secara psikologis sudah memiliki kematangan jiwa untuk menghadapi tantangan hidup (Ryff, 1989). Oleh karena itu, baik Weni maupun Santi bisa menerima kenyataan bahwa kejadian sekarang ini adalah wabah global, tidak ada yang menginginkan wabah virus merajalela. Dengan segala daya upaya, mereka berusaha untuk menyelesaikan pendidikan mereka dengan sebaik-baiknya dan tepat waktu.

Crea dan Francis (2020) menjelaskan bahwa perbedaan kepribadian memengaruhi reaksi emosional terhadap suatu kondisi. Hal ini tergambar pada cerita kedua partisipan dalam penelitian ini. Weni yang lebih suka berteman dan bersosialisasi mempunyai kepribadian ekstrover, dia merasa lebih stres dan cemas terhadap keadaan COVID-19. Sedangkan, Santi yang berkepribadian lebih tertutup atau introver dan tidak terlalu suka bersosialisasi merasa kehadiran COVID-19 ini adalah suatu berkah. Dia bersyukur bahwa dia tidak harus bersosialisasi karena adanya pembatasan sosial berskala besar yang ditetapkan oleh pemerintah Australia. Temuan ini berimplikasi bagi setiap individu yang memiliki karakter ekstrover agar lebih berhati-hati, mengurangi 
rasa cemas, sedih dan stres bahkan depresi berlebihan, supaya terhindar dari penyakit fisik dan mental (Baloran, 2020; Turashvili \& Japaridze, 2012).

Pembelajaran yang baik seharusnya mendorong kompetensi sosial dan emosional individu dalam situasi yang nyaman dan kondusif tanpa adanya ancaman (Frydenberg, Martin, \& Collie, 2017). Pembelajaran di tingkat program doktor ternyata sangat berbeda dengan program sarjana dan magister karena para mahasiswa dituntut harus mandiri, mulai dari belajar, bimbingan disertasi sampai berkegiatan akademik lainnya. Mereka juga harus mampu memotivasi dan mendisiplinkan diri sendiri. Dengan kata lain, kemandirian belajar menjadi salah satu strategi dalam menyelesaikan tantangan pada situasi pandemi COVID-19, sehingga hal ini dapat mengurangi kecemasan seseorang menjalani proses pembelajaran (Ma \& Miller, 2020). Bilecen (2020) mengatakan penggunaan media daring berupa Zoom dan WhatsApp dapat memaksimalkan komunikasi antarsesama. Hal ini sejalan dengan yang dialami baik oleh Weni maupun oleh Santi dalam berkomunikasi, terutama dengan dosen pembimbing mereka. Berdasarkan temuan penelitian, kebijakan institusi pendidikan selama pandemi seharusnya bertujuan untuk memastikan kesehatan fisik dan mental dosen dan mahasiswa, memastikan kualitas pembelajaran mahasiswa dan meningkatkan kemampuan penerapan teknologi pengajaran dosen (Yu, Bodycott, \& Mak, 2019).

Penelitian ini dilaksanakan untuk mengeksplorasi pengalaman emosional mahasiswa Indonesia yang mengikuti program doktor di perguruan tinggi Australia, tantangan emosional yang mereka rasakan dan strategi untuk mengatasi tantangan tersebut selama wabah COVID-19. Emosi yang dialami oleh setiap partisipan dengan adanya COVID-19 ini beragam, tergantung pada kepribadiannya. Bagi individu yang berkepribadian ekstrover, dia tentu merasa lebih sedih, stres dan cemas karena dia tidak bisa bersosialisasi dengan orang banyak. Sedangkan, tipe kepribadian introver memaknai kejadian ini merupakan sebuah berkah tersendiri baginya karena dia tidak perlu berinteraksi sosial secara langsung. Tantangan yang dominan adalah pembelajaran dan konsultasi yang harus dilakukan secara daring dan mandiri dengan dosen pembimbing serta hilangnya kesempatan untuk bisa berdiskusi dengan teman secara tatap muka. Akibatnya, dia merasa kesepian ketika belajar sendiri sehingga motivasi belajar jadi menurun. Kedua partisipan memiliki strategi yang sama untuk mengatasi tantangan tersebut. Mereka bekerja keras, mandiri, dan berkomitmen untuk menyelesaikan tugas-tugas disertasi dan akademik lainnya secara disiplin supaya mereka dapat menyelesaikan pendidikan secepat mungkin.

\section{Pernyataan Penulis [Disclosure Statement]}

Penulis menyatakan bahwa tidak ada konflik kepentingan dalam hal riset, kepengarangan, dan publikasi artikel ini [The authors declared no potential conflicts of interest with respect to the research, authorship, and/or publication of this article]. 


\section{Pernyataan Kontribusi Penulis [Authors' Contribution Statements]}

Supiani: Mengonsep ide (utama), merancang metode penelitian (utama), menulis artikel awal (utama), mengevaluasi (utama), dan mereview dan mengedit (utama) [conceptualization of ideas (lead), methodology (lead), writing-original draft (lead), review (lead), editing (lead)]; Dina Rafidiyah: Mengonsep ide (utama), merancang metode penelitian (penguat), menulis artikel awal (penguat), transkripsi data (utama), mengevaluasi (utama), mengedit (utama) [conceptualization of ideas (lead), methodology (supporting), writing-original draft (supporting), data transcription (lead), review (lead), editing (lead)]; Yansyah: Mengonsep ide (utama), merancang metode penelitian (penguat), menulis artikel awal (utama), pengumpulan data (utama), mengevaluasi (berimbang), mengedit (berimbang) [conceptualization of ideas (lead), methodology (supporting), writing-original draft (lead), data collection (lead), review (equal), editing (equal)]; Hafizhatu Nadia: Mengonsep ide (penguat), merancang metode penelitian (penguat), menulis artikel awal (penguat), pengumpulan data (utama), transkripsi data (utama), mengevaluasi (penguat), mengedit (penguat) [conceptualization of ideas (supporting), methodology (supporting), writing-original draft (supporting), data collection (lead), data transcription (lead), review (supporting), editing (supporting)].

\section{DAFTAR REFERENSI}

Baloran, E. T. (2020). Knowledge, attitudes, anxiety, and coping strategies of students during COVID-19 pandemic. Journal of Loss and Trauma, 25, 635-642. DOI: 10.1080/15325024.2020.1769300

Bao, W. (2020). COVID-19 and online teaching in higher education: A case study of Peking University. Human Behavior and Emerging Technologies, 2(2), 113-115. DOI: 10.1002/hbe2.191

Bilecen, B. (2020). Commentary: COVID-19 pandemic and higher education: International mobility and students' social protection. International Migration, 58(4), 263-266. DOI:10.1111/imig.12749

Braun, V., \& Clarke, V. (2006). Using thematic analysis in psychology. Qualitative Research in Psychology, 3(2), 77-101. DOI: 10.1191/1478088706qp063oa

Brunsting, N. C., Zachry, C., Liu, J., Bryant, R., Fang, X., Wu, S., \& Luo, Z. (2019). Sources of perceived social support, social-emotional experiences, and psychological well-being of international students. The Journal of Experimental Education. Terbit pertama online (hlm. 1-17). DOI: 10.1080/00220973.2019.1639598

Clandinin, D. J., \& Connelly, F. M. (2000). Narrative inquiry: Experience and story in qualitative research. San Francisco, CA: Jossey-Bass.

Crea, G., \& Francis, L. J. (2020). Psychological type and personal wellbeing among Catholic priests in Italy: A study in positive psychology. Mental Health, Religion and Culture. Terbit pertama online (hlm. 1-8). DOI: 10.1080/13674676.2020.1758645

Demuyakor, J. (2020). Coronavirus (COVID-19) and online learning in higher institutions of education: A survey of the perceptions of Ghanaian international students in China. Online Journal of Communication and Media Technologies, 10(3), 1-9. DOI: 10.29333/ojcmt/8286 
Fischer, K. (2020). Confronting the seismic impact of COVID-19: The need for research. Journal of International Students, 10(2), i-ii. DOI: $10.32674 /$ jis.v10i2.2134

Fishman, D. K. (2001). Interpreting qualitative data: Methods for analysing talk, text and interaction. Forum: Qualitative Social Research, 3(6). DOI: $10.1177 / 146879410200200111$

Frydenberg, E., Martin, A. J., \& Collie, R. J. (Eds). (2017). Social and emotional learning in Australia and the Asia-Pacific: Perspectives, programs and approaches. Cham: Springer.

Glass, C. R., \& Westmont, C. M. (2014). Comparative effects of belongingness on the academic success and cross-cultural interactions of domestic and international students. International Journal of Intercultural Relations, 38(1), 106-119. DOI: 10.1016/j.ijintrel.2013.04.004

Harrell, M. C., \& Bradley, M. A. (2009). Data collection methods: Semi-structured interviews and focus groups. Santa Monica, CA: RAND Corporation.

Hawkley, L. C., \& Cacioppo, J. T. (2010). Loneliness matters: A theoretical and empirical review of consequences and mechanisms. Annals of Behavioral Medicine, 4O(2), 218-227. DOI: 10.1007/s12160-010-9210-8

Ma, H., \& Miller, C. (2020). Trapped in a double bind: Chinese overseas student anxiety during the COVID-19 pandemic. Health Communication. Terbit pertama online (hlm. 1-8). DOI: 10.1080/10410236.2020.1775439

Maddamsetti, J., Flennaugh, T. K., \& Rosaen, C. L. (2018). Who should teach? A Chinese teacher candidate's understandings of a good teacher and racialised experiences. Asia-Pacific Journal of Teacher Education, 46(2), 148-166. DOI: 10.1080/1359866X.2017.1399983

Nguyen, O. O. T. K., \& Balakrishnan, V. D. (2020). International students in Australia-during and after COVID-19. Higher Education Research \& Development. Terbit pertama online (hlm. 1-5). DOI: $10.1080 / 07294360.2020 .1825346$

Quattrone, F., Borghini, A., Emdin, M., \& Nuti, S. (2020). Protecting higher education institutions from COVID-19: Insights from an Italian experience. Journal of American College Health. Terbit pertama online (hlm. 1-2). DOI: 10.1080/07448481.2020.1791885

Radley, A. (1979). The social psychology of learning: A 'naïve' description of educational experience. Journal of Further and Higher Education, 3(1), 82-90. DOI: $10.1080 / 0309877790030108$

Ryff, C. D. (1989). Happiness is everything, or is it? Explorations on the meaning of psychological well-being. Journal of Personality and Social Psychology, 57(6), 1069-1081. DOI: 10.1037/0022-3514.57.6.1069

Soong, H., Kerkham, L., Reid-Nguyen, R., Lucas, B., Geer, R., \& Mills-Bayne, M. M. (2020). Reimagining transcultural identity: A case study of field experiences for international preservice teachers. Teaching Education. Terbit pertama online (hlm. 1-17). DOI: 10.1080/10476210.2020.1790516

Tran, L. T. (2020). Teaching and engaging international students: People-to-people connections and people-to-people empathy. Journal of International Students, 10(3). xii-xvii. DOI: 10.32674/JIS.V10I3.2005 
Turashvili, T., \& Japaridze, M. (2012). Psychological well-being and its relation to academic performance of students in Georgian context. Problems of Education in the $21^{\text {st }}$ Century, 49, 73-81.

Van Manen, M. (1990). Researching lived experience: Human science for an action sensitive pedagogy. New York: The State University of New York.

Van Manen, M. (1997). From meaning to method. Qualitative Health Research, 7(3), 345-369.

Widodo, H. P. (2014). Methodological considerations in interview data transcription. International Journal of Innovation in English Language Teaching and Research, 3(1), 101-107.

Wolf, D. M., \& Phung, L. (2019). Studying in the United States: Language learning challenges, strategies, and support services. Journal of International Students, 9(1), 211-224. DOI: 10.32674/jis.v9i1.273

Xue, E., Li, J., Li, T., \& Shang, W. (2020). How China's education responses to COVID-19: A perspective of policy analysis. Educational Philosophy and Theory. Terbit pertama online (hlm. 1-13). DOI: 10.1080/00131857.2020.1793653

Yu, B., Bodycott, P., \& Mak, A. S. (2019). Language and interpersonal resource predictors of psychological and sociocultural adaptation: International students in Hong Kong. Journal of Studies in International Education. Terbit pertama online (hlm. 1-17). DOI: 10.1177/1028315318825336

\section{BIOGRAFI SINGKAT PENULIS [NOTES ON CONTRIBUTORS]}

Supiani (penulis korespondensi) adalah seorang dosen bahasa Inggris di Program Studi S1 Pendidikan Bahasa Inggris, Universitas Islam Kalimantan MAB Banjarmasin, Kalimantan Selatan, Indonesia. Minat riset penulis adalah keterampilan menulis, umpan balik menulis, metodologi pengajaran bahasa Inggris dan motivasi dalam belajar bahasa. Email: supiani.uniska@gmail.com

Supiani (corresponding author) is an English language lecturer in the Department of English Education at Universitas Islam Kalimantan MAB Banjarmasin, South Borneo, Indonesia. His research areas include ESL/EFL writing, written corrective feedback, ELT methodology, and motivation in language learning. Email: supiani.uniska@gmail.com

Dina Rafidiyah adalah dosen di Program Studi S1 Pendidikan Bahasa Inggris, Universitas Muhammadiyah Banjarmasin, Kalimantan Selatan, Indonesia. Penulis tertarik mengkaji pengajaran bahasa Inggris menggunakan teknologi, pendidikan kejuruan dan pengembangan bahan ajar. Email: dinarafidiyah@gmail.com

Dina Rafidiyah is a lecturer in the Department of English Education at Universitas Muhammadiyah Banjarmasin, South Borneo, Indonesia. She is interested in researching technology-enabled language instruction, vocational education, and language materials development. Email: dinarafidiyah@gmail.com 
Yansyah adalah dosen di Program Studi S1 Pendidikan Bahasa Inggris, Universitas Muhammadiyah Banjarmasin, Kalimantan Selatan, Indonesia. Penulis tertarik mengkaji pengajaran bahasa Inggris menggunakan teknologi, pengembangan bahan ajar, bahasa Inggris untuk tujuan khusus dan pengembangan profesi guru. Email: yansyah@umbjm.ac.id

Yansyah is a lecturer in the Department of English Education at Universitas Muhammadiyah Banjarmasin, South Borneo, Indonesia. His research interests are in technology-enabled language learning, language materials development, English for specific purposes, and teacher professional development. Email: yansyah@umbjm.ac.id

Hafizhatu Nadia adalah dosen di Program Studi S1 Pendidikan Bahasa Inggris, Universitas Muhammadiyah Banjarmasin, Kalimantan Selatan, Indonesia. Penulis tertarik mengkaji metodologi pengajaran bahasa Inggris, pengembangan bahan ajar dan pengajaran bahasa Inggris menggunakan teknologi. Email: hafizhatunadia@gmail.com

Hafizhatu Nadia is a lecturer in the Department of English Education at Universitas Muhammadiyah Banjarmasin, South Borneo, Indonesia. Her research interests lie in ELT methodology, language materials development, and technologyenabled language learning. Email: hafizhatunadia@gmail.com 